Bangladesh J. Plant Taxon. 18(2): 141-148, 2011 (December)

(C) 2011 Bangladesh Association of Plant Taxonomists

\title{
A NEW SCAPIGEROUS SPECIES OF IMPATIENS (BALSAMINACEAE) FROM INDIA
}

\author{
M.K. Ratheesh Narayanan, N. Anilkumar, R. Meera Raj, M. Sivadasan ${ }^{1 *}$ \\ AND A.H. AlFarhaN ${ }^{1}$ \\ M. S. Swaminathan Research Foundation, Puthoorvayal 673 121, \\ Kalpetta, Wayanad, Kerala, India
}

Keywords: Balsaminaceae; Impatiens minae; Western Ghats; India; Scapigerous species.

\begin{abstract}
Impatiens minae Ratheesh, Anil Kumar \& Sivad. a new scapigerous species of Impatiens from Wayanad district in Kerala, India is described and illustrated. The new species resembles Impatiens denisonii and I. scapiflora by its 3-lobed lateral united petals and lower sepal with a long spur; but differs from the latter in having a curved band of dense fleshy clavate papillae at the base of lateral united petals, and from the former in the absence of a dorsal filiform appendage or auricle at the base of the lateral united petals.
\end{abstract}

\section{Introduction}

The genus Impatiens L. (Balsaminaceae) is one of the largest and difficult genera of angiosperms comprising over 1000 species (Mabberley, 2008), and several new species are being recognized and described each year. The earliest detailed study of the genus was by Hooker and Thomson (1859); and revision by Warburg and Reiche (1895) with infrageneric classification.

The major contributions on Indian species are those of Hooker (1874-1875, 1904, 1905, 1906). In India the genus is represented by over 203 taxa mainly distributed in three major centres of diversity, i.e. Western Himalayas, North East India and the Western Ghats, each characterized by its own species groups and sections (Hooker, 1910; Gamble, 1915; Rajalal et al., 1996; Vivekananthan et al., 1997). The scapigerous species of Impatiens have very restricted distribution in South Indian-Sri Lankan region with very low diversity and high rate of endemism compared to non-scapigerous species (Grey-Wilson, 1980; Nair, 1991; Vivekananthan et al., 1997). Except Impatiens acaulis, which is distributed throughout the wet tropical forests of Western Ghats and Sri Lanka, all other species have very narrow distribution pattern in various small microcenters in Western Ghats, especially in its southern part. They are highly delicate ephemerals thriving mainly on moss covered tree-trunks or on wet rocks for a short duration in monsoon season. Classification of the 'Scapigerae' section is mainly based on the lobes of the lateral petals, the spur of the lip and the dorsal auricle on the lateral petals. Vivekananthan et al. (1977) reported 19 species of scapigerous Impatiens from Western Ghats in his treatment for the flora of India, and the major centre of distribution is considered to be Nilgiri phytogeographical region of southern Western Ghats (Bhaskar, 1981, 2006; Bhaskar and Razi, 1982; Vivekananthan et al., 1997; Viswanathan

*Corresponding author. E-mail: drmsivadasan@rediffmail.com

${ }^{1}$ Department of Botany \& Microbiology, College of Science, King Saud University, P. O. Box 2455, Riyadh 11451, Kingdom of Saudi Arabia. 
and Manikandan, 2003). Out of the 30 species of Impatiens reported from Periyar Tiger Reserve in Kerala, 3 are scapigerous (Augustine et al., 1999). In a recent study Dessai and Janarthanam (2011) recognized seven scapigerous species in the northern and parts of central Western Ghats.

During the floristic exploration of Wayanad district in Kerala which is unique for its rich and diverse flora and home of several endemics (Sivadasan and Balakrishnan, 1989; Sivadasan and Jaleel, 2002; Narayanan et al., 2010a; Narayanan et al., 2010b), interesting specimens of scapigerous Impatiens with a spur of lower sepal longer than $3 \mathrm{~cm}$ and a curved band of dense fleshy papillae at basal part on the lateral united petals were collected from two different localities in southern Wayanad. Critical examination revealed that the specimens are quite distinct from hitherto known scapigerous species of Impatiens, and is described and illustrated here as a new species.

Impatiens minae Ratheesh, Anil Kumar \& Sivad., sp. nov.

(Figs 1, 2)

Diagnosis: Impatiens denisonii Bedd. et Impatiens scapiflorae Heyne ex Roxb. connatolateralio-petalis 3-lobatis, infero-sepalis longe calcaratis similis, sed ab I. denisonii connatolateralio-petalis dorsaliter base haud filiformio-appendiculatis et ab I. scapiflorae ad minimosupra bases dense carnoso-petalloide papillatis, papillis in curvato-vittam dispositis differt.

Types: India, Kerala: Wayanad District, Chembra hills, Rocky grasslands, $11^{\circ} 30.716^{\prime} \mathrm{N}$, 76 06.239'E , \pm 1700 m, 17 August 2006, M. K. Ratheesh Narayanan MSSH 1113 (Holotype: CAL; Isotype: $\mathrm{MH}$; Community Herbarium, Scarascia Magnozza Genetic Resource Centre, MSSRF, Chennai; Herbarium of the M. S. Swaminathan Research Foundation, Kalpetta).

Paratypes: India, Kerala: Wayanad District, Chembra hills, Rocky grasslands, $11^{\circ} 30.716^{\prime} \mathrm{N}$, 7606.239' E , \pm 1700 m, 23 July 2009, Ratheesh Narayanan MSSH 4815 (MH; Community Herbarium, Scarascia Magnozza Genetic Resource Centre, MSSRF, Chennai; Herbarium of the M. S. Swaminathan Research Foundation, Kalpetta).

Scapigerous terrestrial herbs, $25-30 \mathrm{~cm}$ high; rootstock tuberous. Leaves 3-5, radical, fleshy, 5-8 $\times 5-7 \mathrm{~cm}$, ovate-orbicular or reniform, obtuse or rounded at apex, base cordate, margin crenate or serrate, finely hairy, pinkish green above, glabrous, pale green below, primary veins usually 6, palmate; petioles up to $8 \mathrm{~cm}$ long, pink. Scape racemose, many-flowered (up to 15), 25$30 \mathrm{~cm}$ long, glabrous. Flowers clustered at the apex, deep pink, each c. $2.5 \mathrm{~cm}$ across; pedicels 2.0-2.5 cm long; bracts thick, fleshy, broadly ovate, obtuse, $3-5 \times 2-3 \mathrm{~mm}$, reddish green. Lateral sepals 2, each 3.0-4.0 × 2.0-2.2 mm; lower sepals long-spurred, spur slender, 3.0-3.5 cm long, pink, slightly recurved or pendent. Dorsal petals broadly orbicular, saccate, 5-6 $\times 5-7 \mathrm{~mm}$; lateral united petals 3-lobed, pink, with a slightly curved band of dense red-tipped clavate papillae just above base; basal lobes slightly larger than the distal lobes, curved outwards, c. $1 \mathrm{~cm}$ long, broadly oblong, rounded; middle lobes broader towards tip, c. $8 \mathrm{~mm}$ long, broadly obovate; distal lobes strap-shaped, c. $8 \mathrm{~mm}$ long. Stamens 5 , connate, c. $1.8 \times 1.4 \mathrm{~mm}$; filaments white with pink tinge above; anthers pale blue. Ovary pale yellowish green, 1.7-1.8 $\times 1.0-1.3 \mathrm{~mm}$, elliptic, broadly acute 


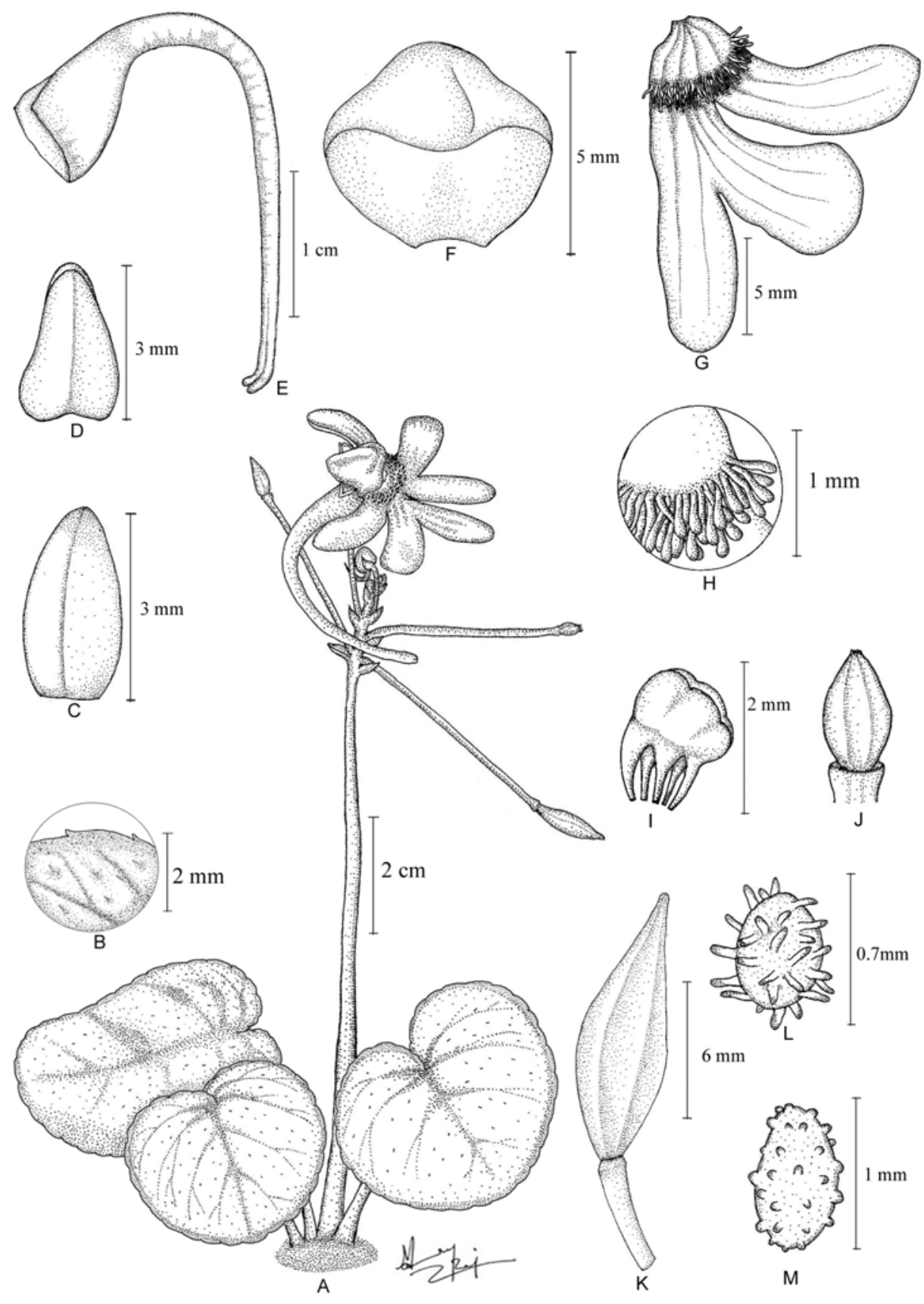

Fig. 1. Impatiens minae Ratheesh, Anil Kumar \& Sivad. sp. nov. A, Habit; B, A portion of leaf margin enlarged; C, Bract; D, Lateral sepal; E, Lower spurred sepal; F, Standard petal; G, Lateral united petals; H, Papillae on the lateral united petals - enlarged; I, Anthers; J, Gynoecium; K, Fruit; L, Immature seed; M, Mature seed. (Drawn from M. K Ratheesh Narayanan MSSH 4815, Community Herbarium, Scarascia Magnozza Genetic Resource Centre, MSSRF, Chennai). 
at apex, glabrous. Capsule glabrous, reddish green, broadly ellipsoid, apex acute, 1.3-1.8 cm long. Seeds numerous, c. $1 \mathrm{~mm}$ long, outside short-blunt spinous.

Impatiens minae is allied to Impatiens denisonii Bedd. and Impatiens scapiflora Heyne ex Roxb., but distinctly differs from both by the characters given in the Table 1

Table 1. Diagnostic morphological characters of Impatiens minae and related species

\begin{tabular}{llll}
\hline Characters & \multicolumn{1}{c}{ I. denisonii } & \multicolumn{1}{c}{ I. minae } & \multicolumn{1}{c}{ I. scapiflora } \\
\hline Leaves & $\begin{array}{l}\text { Ovate, apex acute, base } \\
\text { cordate, with deep sinus, } \\
\text { densely hairy, pink, } 7.0-15.0 \\
\times 7.5-10.0 \mathrm{~cm}\end{array}$ & $\begin{array}{l}\text { Broadly ovate-orbicular, } \\
\text { thick, fleshy, apex obtuse } \\
\text { or rounded, base cordate, } \\
\text { densely hairy, deep pink, }\end{array}$ & $\begin{array}{l}\text { Orbicular or broadly ovate, } \\
\text { base cordate with deep sinus, } \\
\text { sparsely hairy, green, } 8-15 \times \\
5-12 \mathrm{~cm}\end{array}$ \\
$\begin{array}{l}\text { Spur of } \\
\text { flower }\end{array}$ & $\begin{array}{l}3-4 \mathrm{~cm} \text { long, strongly } \\
\text { recurved, pink }\end{array}$ & $\begin{array}{l}3.0-3.5 \mathrm{~cm} \text { long, slightly } \\
\text { curved or pendent, pink }\end{array}$ & $\begin{array}{l}\text { 4-6 cm long, strongly } \\
\text { recurved, white }\end{array}$ \\
$\begin{array}{l}\text { Lateral } \\
\text { united } \\
\text { petals }\end{array}$ & $\begin{array}{l}\text { With long dorsal } \\
\text { filamentous } \\
\text { appendage/auricle produced } \\
\text { into the spur }\end{array}$ & $\begin{array}{l}\text { Without a dorsal } \\
\text { appendage/auricle }\end{array}$ & $\begin{array}{l}\text { Without a dorsal } \\
\text { appendage/auricle }\end{array}$ \\
$\begin{array}{l}\text { Papillae on } \\
\text { lateral } \\
\text { united } \\
\text { petals }\end{array}$ & $\begin{array}{l}\text { A curved band of pink with } \\
\text { red-tipped petaline papillae } \\
\text { present just above the base } \\
\text { of lateral united petals }\end{array}$ & $\begin{array}{l}\text { A curved band of pink } \\
\text { with red-tipped petaline } \\
\text { papillae present just above } \\
\text { the base of lateral united } \\
\text { petals }\end{array}$ & $\begin{array}{l}\text { Band of petaline papillae } \\
\text { absent on the lateral united } \\
\text { petals }\end{array}$ \\
Seeds & $\begin{array}{l}\text { Surface covered with spiral } \\
\text { hairs }\end{array}$ & $\begin{array}{l}\text { Surface with short blunt } \\
\text { spinous projections }\end{array}$ & Surface hispid \\
\hline
\end{tabular}

Etymology: The specific epithet of the new taxon is in honour of Ms. Mina Swaminathan, Advisor, M. S. Swaminathan Research Foundation, who has dedicated her life for the education and empowerment of underprivileged children and women in rural areas, and also in creating awareness among them on values and importance of biodiversity and its conservation.

Notes: Impatiens minae resembles I. denisonii Bedd. and I. scapiflora Heyne ex Roxb. in having 3-lobed lateral united petals and lower sepal with a long spur, but differs from I. denisonii by its fleshy, broadly ovate-orbicular leaves, absence of a dorsal filamentous appendage or auricle at the base of lateral united petals, and seeds having short, blunt spinous projections. It differs from I. scapiflora in having a slightly curved band of dense clavate papillae just above the base of lateral united petals. The seed-surface in I. scapiflora are hispid in contrast to the short, blunt spinous projections in I. minae.

Phenology: Flowering starts from July and peak time is August. Fruit matured during September-October.

Distribution and ecology: So far known only from the Chembra-Vellarimala hill ranges of Wayanad district in Kerala (Fig. 3). Grows in open wet and dripping rocky slopes in grasslands at 
altitudes of 1600-2000 m associated with Habenaria rariflora A. Rich., Ipsea malabarica Hook. f., Satyrium nepalense D. Don, Chlorophytum malabaricum Baker, Eriocaulon spp., etc.
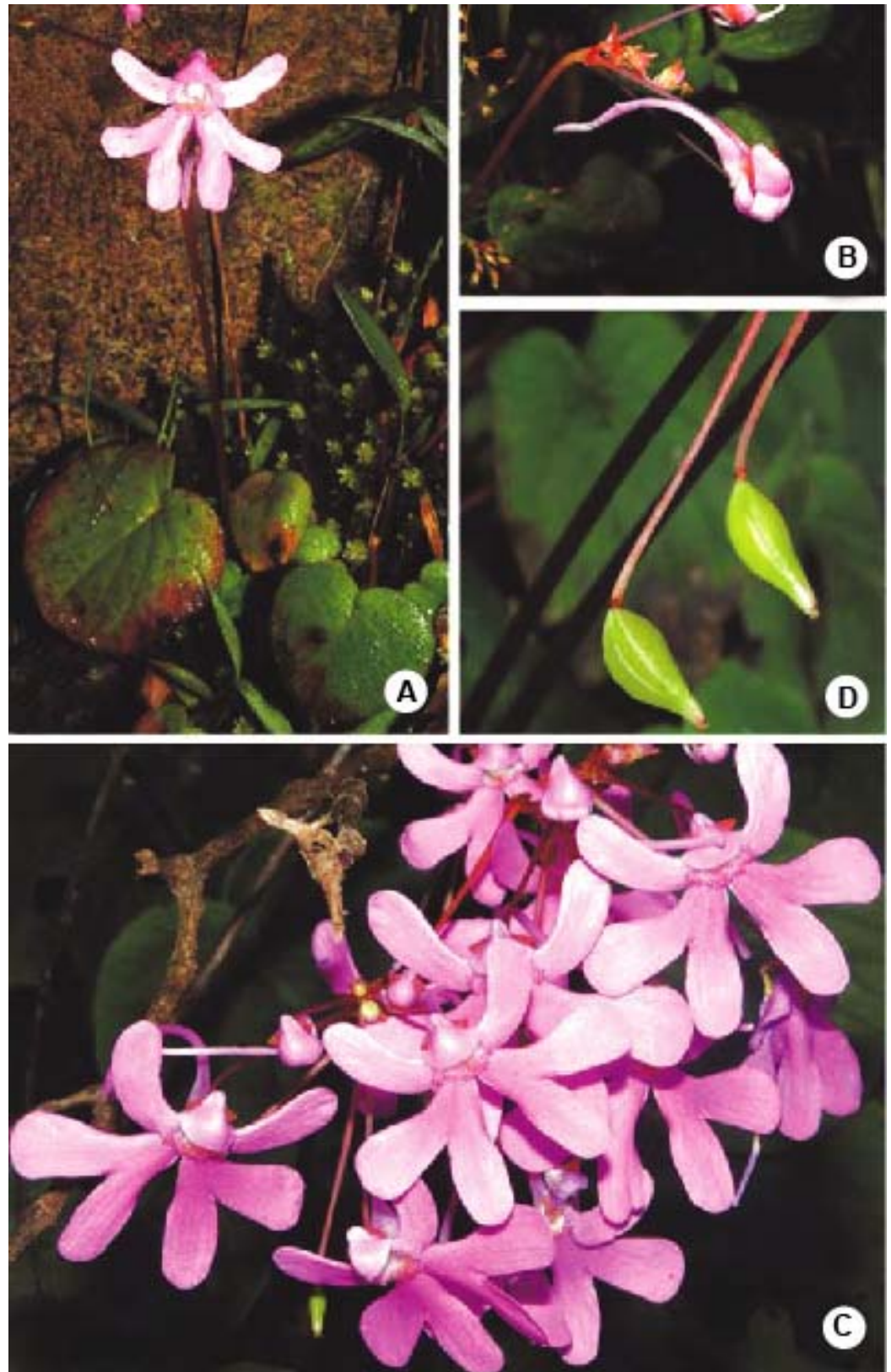

Fig. 2. Impatiens minae Ratheesh, Anil Kumar \& Sivad. sp. nov. A, Habit; B, Flower bud; C, Flowers; $\mathrm{D}$, Young fruits. 


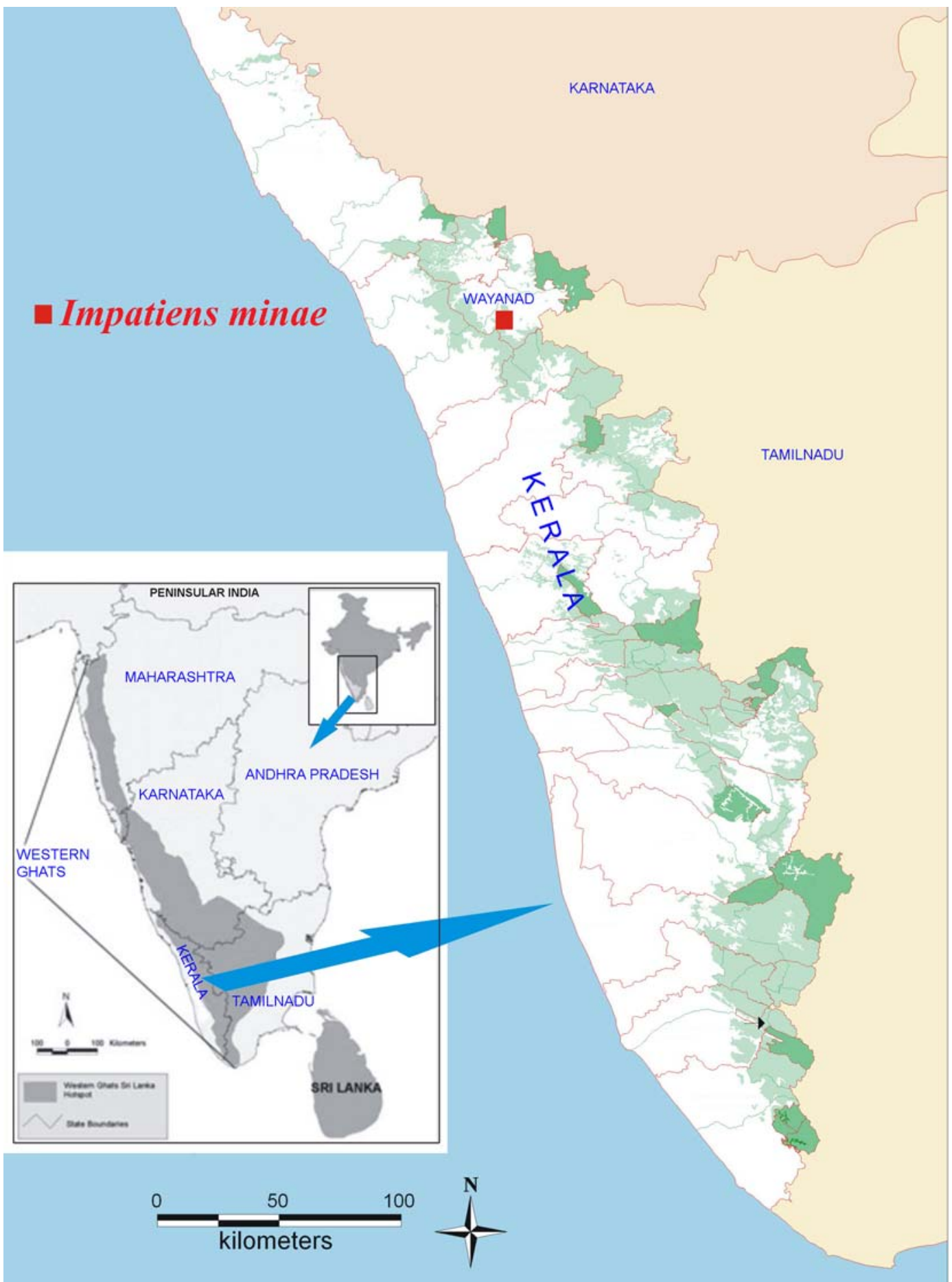

Fig. 3. Distribution of Impatiens minae Ratheesh, Anil Kumar \& Sivad. sp. nov. in India. 
Population structure and conservation status: The species is seen in open grassy slopes in clusters along with grasses, mainly along the slopes between 1500 and $1700 \mathrm{~m}$ above the sea level of Chembra-Vellarimala hill ranges. It is observed that they are distributed in isolated patches from southern to northern part of the hill ranges. The southern most population is located in the high altitude grassy slopes of south-east side of Chembra hills of Meppady forest range and major population is in the north-west slopes of the Chembra hills belonging to the same forest range of Wayanad district. The populations are small and scattered along this hill ranges and are restricted to 30 sq. km area. This hill ranges are not under any protected areas. Increased anthropogenic interference in the form of tourism and forest fire enhance the crisis. Its geographic range (extent of occurrence) and the quality of habitat are declining continuously. By following IUCN criteria (IUCN, 2001) for assessing the status of Rare and Threatened plants, M. minae is assessed as belonging to Critically Endangered (CR) category.

\section{Acknowledgments}

The authors are grateful to the Chairman Prof. M. S. Swaminathan, and Executive Director of M. S. Swaminathan Research Foundation, Chennai, India for providing facilities and support. The valuable comments on the novelty of the species by Mr. M. D. Theuerkauf, Gurukula Botanical Sanctuary, North Wayanad, Kerala, logistics provided by the Forest Department, Government of Kerala for the fieldwork, and help rendered by staff of Community Agrobiodiversity Centre of M. S. Swaminathan Research Foundation, Kalpetta are thankfully acknowledged. The last two authors extend their appreciation to the Deanship of Scientific Research at King Saud University for support through the research group project No. RGP-VPP-135.

\section{References}

Augustine, J., Sasidharan, N. and Sivadasan, M. 1999. Balsams of Periyar Tiger Reserve, southern Western Ghats, Kerala. In: Sivadasan, M. and Philip Mathew (eds.), Taxonomy and conservation of flowering plants. Mentor Books, Calicut, India, pp. 275-292.

Bhaskar, V. 1981. The genus Impatiens in South India: Endemism and affinities. Indian Forester 107(6): 368378.

Bhaskar, V. 2006. Impatiens clavata Bhaskar sp. nov. - a new scapigerous balsam (Balsaminaceae) from Bisle Ghat, Western Ghats, South India. Current Science 91(9): 1138-1140.

Bhaskar, V. and Razi, B.A. 1982. Two more new species of Impatiens from South India. J. Bombay Nat. Hist. Soc. 79: 382-384.

Dessai, J.R.N. and Janarthanam, M.K. 2011. The genus Impatiens (Balsaminaceae) in the northern and parts of central Western Ghats. Rheedea 21(1): 23-80.

Gamble, J.S. 1915. Impatiens. In: Flora of the Presidency of Madras. Adlard \& Sons Ltd., London, pp. 134145.

Grey-Wilson, C. 1980. Impatiens of Africa. A. A. Balkema, Rotterdam.

Hooker, J.D. 1874-75. Geraniaceae-Balsamineae. In: Flora of British India 1. L. Reeve \& Company, London, pp. 440-483.

Hooker, J.D. 1904. An epitome of the British Indian species of Impatiens. Rec. Bot. Surv. India 4 (1): 1-10.

Hooker, J.D. 1905. An epitome of the British Indian species of Impatiens. Rec. Bot. Surv. India 4(2): 11- 35. 
Hooker, J.D. 1906. An epitome of the British Indian species of Impatiens. Rec. Bot. Surv. India 4(3): 37-58.

Hooker, J.D. 1910. Indian species of Impatiens. Generis Impatiens species Indicae novae et minus rite cognitae a cl. Meebold detectae. Bull. Misc. Inform. 1910: 291-300.

Hooker, J.D. and Thomson, T. 1859. Praecursores ad Floram Indicam.-Balsamineae. J. Proc. Linn. Soc. Bot. 4: 106-157.

IUCN, 2001. IUCN Red List Categories and Criteria (version 3.1). IUCN, Gland, Switzerland and Cambridge, U. K.

Mabberley, D.J. 2008. Plant Book - A Portable dictionary of the vascular plants, their classification and uses, ed. III. Cambridge University Press, Cambridge, UK.

Nair, N.C. 1991. Endemism on the Western Ghats with special reference to Impatiens L. In: Proceedings of the Symposium on Rare, Endangered and Endemic Plants of Western Ghats. Special Publication No. III. Kerala Forest Department (Wildlife Wing), Thiruvananthapuram, India, pp. 92-102.

Narayanan, M.K.R., Manudev, K.M., Sujanapal, P., Anilkumar, N., Sivadasan, M. and Alfarhan, A.H. 2010a. Oberonia swaminathanii sp. nov. (Orchidaceae) from, Kerala, India. Nord. J. Bot. 28: 713-715.

Narayanan, M.K.R., Sujanapal, P., Anilkumar, N., Sasidharan, N., and Sivadasan. M. 2010b. Miliusa wayanadica (Annonaceae), A new species from Western Ghats, India. J. Bot. Res. Inst. Texas 4(1): 6367.

Rajalal, R., Pandurangan, A.G. and Pushpangadan, P. 1996. Systematic studies of Balsaminaceae in Peninsular India. J. Swamy Bot. Club 13: 59-62.

Sivadasan, M. and Balakrishnan, R.T. 1989. Oberonia wynadensis, a new species of Orchidaceae ftom India. Nord. J. Bot. 9: 395-397.

Sivadasan, M. and Jaleel, V.A. 2002. Two new varieties of Amorphophallus commutatus (Schott) Engl. (Araceae) from India. Rheedea 12(2): 155-157.

Viswanathan, M.B. and Manikandan, U. 2003. A new species of Balsaminaceae, Impatiens tirunelvelica, from Peninsular India. Bull. Bot. Surv. India 45(1-4): 189-194.

Vivekananthan, K., Rathakrishnan, N.C., Swaminathan, M.S. and Ghara, L.K. 1997. Balsaminaceae. In: Hajra, P.K., Nair, V.J. and Daniel, P. (eds.), Flora of India, 4. Botanical Survey of India, Calcutta, India, pp. 95-229.

Warburg, O. and Reiche, K. 1895. Balsaminaceae. In: Engler, H.G.A. and Prantl, K.A.E. (eds.), Die naturlichen Pflanzenfamilien, Teil 3, Abteilung 5. Wilhelm Engelmann, Leipzig. 